of energy available for and adaptable to manufacturing purposes. Among these water-power stands pre-eminent, especially since the introduction of electricity, which has provided an easy and convenient means for the transmission of its energy. Then, in regard to flood prevention, domestic water supply, irrigation, and land reclamation there are obvious grounds for regarding the study of periodic flow in rivers and streams as a consideration of the highest importance. The damage arising from floods in the United States exceeds a hundred million dollars annually, and more than 70 million acres of the richest land are rendered practically worthless by reason of prevailing conditions of overflow and swamp. Amelioration of these natural defects can only be brought about by the collection of trustworthy data and a careful and thorough study of all the circumstances attending the phenomena in question.

Records of stream flow necessarily call for frequent and prolonged observation. They must embrace all stages and cover, if possible, the absolute maximum and the absolute minimum of discharge. This involves, in most cases, a period of at least five or ten years, and in some instances twenty years or more. It is regrettable that the compilers of these volumes have had to avow that a number of their records are of insufficient duration, owing to unforeseen reduction in grants and the consequent abandonment of certain gauging stations. The national exchequer is surely not so impoverished as to be under the necessity of exercising retrenchment in regard to so important a branch of the public service.

Three methods of stream-flow measurement have been adopted by the Hydrographical Department, according to the local physical conditions, the degree of accuracy desired, the funds available, and the length of time devoted to observation.

The first, most theoretical, and least used method is that of measuring the slope and cross-section of a stream, and then using the Kutter expansion of Chezy's formula. Owing to the difficulty of obtaining accurate data, and more particularly to the uncertainty attaching to the coefficients in the formula, results obtained by this method can only be regarded as approximately correct.

The second method is that of measuring the discharges over dams and weirs. Here the problem is complicated by variations in profile and crest, by leakages through the dams, backwater at high stages, log and ice obstructions, and local diversions of water for power purposes. On this account comparatively few stations are maintained at weirs and dams.

The system chiefly employed is that of measuring the velocity of the current, principally by the Price current meter, rarely by means of free floats, and, at the same time, determining by a series of ordinates from a datum line the cross-sectional area of the stream.

The following comments on the relative merits of the systems are interesting.

"Practically all discharge measurements made under fair conditions are well within 5 per cent. of the true discharge at the time of observation. Inasmuch as the errors of meter measurements are largely compensating, the mean rating curve, when well defined, is much more accurate than the individual measurements. Numerous tests and experiments have been made to test the accuracy of current-meter work. These show that it compares very favourably with the results from standard weirs, and, owing to simplicity of methods, usually gives results that are much more reliable than those from stations at dams, where uncertainty regarding the coefficient and complicated conditions of flow prevail.'

Then there is, of course, the human element and the personal factor which enters into all experimental work. It is interesting to know that, "with relatively few exceptions, the observers perform their work honestly." Yet even honesty of purpose cannot eliminate every element of error, though the effect of numerous readings is obviously to minimise any inadvertent inexactitudes. Individualism counts for something, too, but, on the whole, errors arising from these and other causes become self-compensating and virtually negligible.

Merely to enumerate all the river basins comprised within the purview of the Hydrographical Survey would involve more space than can be spared for the purpose. NO. 2 I 48 , VOL. 85$]$
From the noble Mississippi, with its drainage area of I, 240,000 square miles, including wholly, or in part, thirty States, besides a small portion of the Dominion of Canada, down to the modest Siletz, with its length of 50 miles and its basin of 320 square miles, there are measured and described all sorts and conditions of streams with names as musical as Menonimee and Wapsipinicon, as dissonant as Umpqua and Puyallup, prosaic as Muddy and fantastic as Devil's. The whole area of the country is to be covered by a dozen bulletins, of which the present seven form part.

B. C.

\section{PALAEONTOLOGICAL PAPERS.}

THE troublesome question of fucoids has exercised $\mathrm{Mr}$. Otto M. Reis ("Zur Fucoidenfrage," Jahrb. k.k. geol. Reichsanstalt, Bd. lix., published 1910, p. 6r5), an author well known for his researches on ruin-marble and cone-in-cone. He accepts an organic origin for the fucoids collected by him in the northern Apennines and the Alps, and points out that the clay, which might be regarded as a mere infilling of a worm-tube, is in some cases so arranged as to form a true wall to the tube. The granulations on the surface of many fucoids may be regarded as due to clay-lumps used in the construction of the worm-tube. Terebella figulus is cited (p. 628) as an example of a worm that kneads up fine clay into bricks, as it were, which it places from its mouth on to the growing margin of its tube. The author expects criticism, since he sets aside the algal theory of the origin of fucoids in the Flysch, and ascribes the structures to boring and tubicolous worms.

Mr. E. W. Vredenburg (Records, Geol. Survey of India, vol. xxxvi., I908, p. 24I) has described certain "pseudofucoids" of eastern Baluchistan as casts of worm-burrows and tracks of marine organisms, here following the work of Nathorst.

Mr. M. D. Zalessky records (Bull. Acad. imp. Sci. St. Pétersbourg, No. 6, I910) in a brief English paper the discovery of coal-balls in the Carboniferous of the Donetz basin, containing well-preserved plants, from the study of which much may be expected. Their mode of occurrence precisely resembles that of the English examples studied by Williamson.

Mr. Vredenburg (Rec. Geol. Surv. India, vol, xxxvi. p. I7I) describes species of Orbitoides from the upper par of the Upper Cretaceous of India, including megaspheric and microspheric forms. As usual, this author interestingly connects his palæontological work with zonal considerations and with questions of Indian stratigraphy, which here occupy twenty-five pages of the paper.

The important manuscript work on dendroid graptolites, left by Dr. R. Gurley, has been revised and issued by Mr. R. S. Bassler (Bull. 65, U.S. National Museum, I909). The forms described, including many species of Dictyonema, are from the Niagaran (Middle Gotlandian) Dolomites of Hamilton, Ontario. With one or two exceptions, like the Inocaulis on p. 48 , the figures of these difficult fossils are limited to the forms of the rhabdosomes.

Proceeding to molluscs, Dr. A. Schmidt has examined the Anthracosiidæ of the Upper Carboniferous beds of Mährisch-Ostrau (Jahrb. k.k, geol. Reichsanstalt, Bd. lix., published in I910, p. 733). The forms illustrated have naturally an interest for English geologists, and the paper both supports and supplements the work of Dr. Wheelton Hind. Dr. Schmidt points out the general tendency towards a uniform type of shell among the later members of this fresh-water group, while the animals very probably remained quite distinct. The reduction of hingeteeth seems related to prolonged fresh-water conditions. The author doubts if the fresh-water shells of the Mesozoic era had fresh-water Palæozoic ancestors, since the Permian forms had already proceeded far towards uniformity of type, and probably altogether passed away. However, a mollusc described by Mr. L. J. Wills in a paper on the Keuper of Worcestershire, to be quoted later, seems possibly a survival of Naiadites. In the same volume of this Jahrbuch (p. 407, published in roog) Dr. A. Till continues his work on the jaws of fossil cephalopods. In the absence of any guide to their correlation, these objects are 
classed under the genus Hadrocheilus, and are distinguished by numerous specific names.

Mr. G. C. Crick describes a new genus and species of dibranchiate cephalopod, Belemnocamax boweri, from the Lower Chalk (Totternhoe Stone) of Lincolnshire (Proc. Geol. Assoc., vol. xxi., 19 10, p. 360). Belemnocamax resembles Actinocamax generally, but has a broad ventral furrow, and fine longitudinal striæ near the point of the guard.

Dr. A. Till (Verhandl. k.k. geol. Reichsanstalt, 1909, p. 194) establishes a new genus, Villania, for an ammonite allied to Perisphinctes, found in an Oxfordian horizon at Villany, in Hungary.

Mr. T. D. A. Cockerell continues his studies of Tertiary insects (Am. Journ. Sci., vol. xxvii., 1909, p. 381), introducing three new genera, and Mr. H. F. Wickham (ibid., vol. xxix., 1910, p. 47) compliments him by describing Calosoma cockerelli, among other fossil Coleoptera from the Florissant (Oligocene) deposits of Colorado.

Mr. L. J. Wills (Proc. Geol. Assoc., vol. xxi., I9ı, p. 302), in a paper on the fossiliferous Lower Keuper rocks of Worcestershire, describes in considerable detail three species of Mesophonus, a new scorpion, fragmental remains of which occur abundantly at Bromsgrove. Numerous photographs of these remains are given, as well as of the plants from the same strata.

Mr. Bashford Dean's studies on fossil fishes (sharks, chimæroids, and arthrodires) forms part $v$. of the ninth volume of the Memoirs of the American Museum of Natural History (1909). The memoir is finely illustrated, and deals mainly with the cladoselachians of the Devonian period, which are viewed, in agreement with the opinion of Dr. A. S. Woodward, as primitive sharks. The author regards them as nearer the earliest fish-type than are the acanthodians of the Upper Silurian epoch (p. 247). Photographs and descriptions of mounted skulls of Dinichthys and Titanichthys are also given.

The distribution of the Deinosauria in time and through geographical areas is the subject of a memoir by $\mathrm{Mr}$. R. S. Lull (Am. Journ. Sci., vol. xxix., I910, p. 1). As the result of a wide range of reading, the author has drawn up distributional tables, and maps illustrating the probable routes of migration. The maps furnished by De Lapparent for various Mesozoic periods are found to supply the necessary bridges between existing lands in which deinosaurian remains have been found. Incidentally, several suggestive remarks are made. On p. 5 bipedal movement is associated with the necessity for rapidly traversing lands increasing in aridity. The bipedal lizards of the present day occur in semi-arid areas. The carnivorous and bipedal deinosaurs, the Theropoda, are the most widely distributed, and appear to have followed any other forms that furnished them with food. The armoured and herbivorous Orthopoda are regarded as originating with Scelidosaurus of the English Lias, and as having become sluggish and quadrupedal in the course of time, when their heavy armour rendered them impregnable (p. Ir). At this period, including the epochs when Polacanthus and Triceratops flourished, vegetation and water seem to have been abundant. The mystery of the extinction of the deinosaurs is not lightened by the passing reference to geographical conditions on p. 37 .

Mr. Harold Brodrick (Proc. Liverpool Geol. Soc., vol. $\mathrm{x}$. , part v., I909, p. 327) describes and figures footprints, doubtless deinosaurian, found by him in the Inferior Oolite at Saltwick, south of Whitby. It would be very interesting to know if the zone also contains marine fossils, in view of Mr. Lull's comparison of aquatic deinosaurs and hippopotamuses, the latter having been seen to move from estuary to estuary through sea-water.

Mr. A. Zdarsky contributes a memoir on the Miocene Mammalia of Leoben, in Styria, to the Jahrbuch der k.k. geologischen Reichsanstalt, Bd. lix., I909, p. 245. These occur in a terrestrial sandstone above clay and brown coal, the last-named stratum resting on Palæozoic slates. Various rhinoceroses and Suidæ occur. Among the latter, the author places a new genus and species, Xenochoerus leobensis (p. 264), represented by part of a mandible and a row of teeth from the upper jaw. Mastodon and Deinotherium are both present, and the deposit appears (p. 287) to be of Middle Miocene age.

Mr. Franz Toula, in the same journal (Bd. lix., 19ıo, NO. 2 I 48 , VOL. 85 ] p. 575), records the results of an investigation of a preglacial or interglacial bone-deposit near Kronstadt, in Transylvania. The mammalian remains collected from this in recent years have become somewhat scattered; but the author has examined most of them, and especially describes the teeth of a new form, Rhinoceros kronstadtensis (p. 580 ). Among the bones of Cervus there is a phalange that suggests the presence of the giant deer of Ireland.

The Sitzungsberichte vom naturhistorischen Verein der preussischen Rheinlande und Westfalens for 1908 (published in 1909) contains numerous abstracts of papers read before its component societies. Dr. Elbert described at Münster (Section C, p. $5 \mathrm{I}$ ) his expedition to Java in search of the predecessors of the human race. It may be well to recall that he found traces of hearths in deposits that showed the existence of man side by side with Stegodon. $\mathrm{He}$ believes that primaval man entered Java with the Siwalik fauna at the close of Cainozoic times, and that Pithecanthropus was entombed during a cold "diluvial" epoch, when floods were caused by the action of lavas on the snows. The evidence for this colder epoch is furnished by the fossil plants of the Kendeng beds, which represent species that now live at much higher elevations. Dr. Elbert considers that Pithecanthropus was forced to retreat before primæval man, while a land-connection was still open with Celebes, and that various pigmy races may have descended from this genus.

Without entering seriously on the literature of primitive man as a branch of palæontology, we may perhaps direct attention to the spirited description by the late Commandant Molard of the prehistoric drawings of animals in the cave of Niaux, in Ariège (Spelunca, tome vii., p. 3) and to Dr. Florentino Ameghino's illustrated account, previously promised, of stone implements found near Mar del Plata. The latter paper (Anales del Museo Nacional de Buenos Aires, tomo xx., April 22, p. 189) maintains that the pebbles with chipped ends are in some ways more primitive than eoliths, and attributes them to Homo pampaeus of the Tertiary era.

G. A. J. C.

\section{A MONOGRAPH OF THE JELLYFISHES. ${ }^{1}$}

$A \mathrm{NY}$ attempt to arrange the Medusæ of the world in A a natural and convenient zoological system is beset with so many exceptional difficulties that the author of this very fine monograph must at least be congratulated on the courage he has shown and the patience he has exhibited in preparing and publishing his work.

Since Haeckel wrote his famous "System der Medusen" in 1879 there has been no other standard monograph on the group for systematic zoologists to consult, and the need for a comprehensive revision of his classification has been acutely felt. In many cases the forms which Haeckel described as distinct genera have proved, in the light of more modern research, to be but stages in the development of one genus; many new genera and species have been described, and our knowledge of the life-history, anatomy, and physiology of many of the old species has been very widely extended. To bring together the results of all these investigations into one great monograph, to criticise, and to rearrange the genera, is the task which Mr. Mayer has attempted, and, it may be said, with no small measure of success.

The principal difficulty in the systematic arrangement and nomenclature of the Medusæ arises from the fact that in some cases, but not in all, the free-swimming, bell-like and sexually mature organism represents only a stage in the life-history of an individual, or the detached sexual organ of an individual which has an altogether different form, and there are many examples of the sedentary or hydroid stage of a species being known by one generic name and the free-swimming or medusoid stage by another. It may have been an ideal of the earlier writers, which they themselves could not hope to attain, that ultimately the sum total of the life-history of a single species would be united under one generic and one specific name. But this ideal appears to be in these days not only

1 " Medus of the World." By Alfred Goldsborough Mayer. 3 Vols. Vol. i., pp. iv $+2 \xi 0+x v$; vol. ii., pp. iv $+231-4 c 8+x v$; Vol. iii., pp. iv + $499-735$. (Carnegie Institution of Washington, 1910.) 